\title{
Quality in NDT - two approaches
}

\section{Jakość w badaniach NDT - dwa podejścia}

\section{Abstract}

Quality in NDT is the key for safety of constructions and facilities. Two different approaches will be presented. The first approach deals with proficiency tests of nondestructive testing. A procedure offered by the German Society for NDT will be presented.

The second approach deals with vocational education in Germany. Starting in August 1st this year, vocational education of young people is available within the field of nondestructive testing of materials. This education is a stateorganized training offered by state vocational schools under the umbrella of the German Chamber of Industry and Commerce. The presentation will show how this new branch of education is linked to the qualification and certification requirements of the standard EN ISO 9712.

\section{Introduction}

Quality in NDT is the key for safety of constructions and facilities. Two different approaches will be presented. The first approach deals with proficiency tests of non-destructive testing. A procedure offered by the German Society for NDT will be presented.

The second approach deals with vocational education in Germany. Starting in August 1st this year, vocational education of young people is available within the field of non-destructive testing of materials. This education is a state-organized training offered by state vocational schools under the umbrella of the German Chamber of Industry and Commerce. The presentation will show how this new branch of education is linked to the qualification and certification requirements of the standard EN ISO 9712.

Dipl.-Inf. Hannelore Wessel-Segebade - German Society for NDT.

\section{Streszczenie}

Jakość badań nieniszczących jest podstawowym czynnikiem dla bezpieczeństwa konstrukcji i urządzeń. W artykule są przedstawione dwa różne podejścia do tego zagadnienia. Pierwsze wiąże jakość badań z ich sprawnością i przedstawia procedurę oferowaną przez Niemieckie Towarzystwo Badań Nieniszczących.

Drugie podejście związane jest $\mathrm{z}$ edukacją zawodową w Niemczech. Od 1 sierpnia tego roku jest dostępne szkolenie zawodowe młodych ludzi w dziedzinie badań nieniszczących. Szkolenie to jest oferowane przez szkoły państwowe pod patronatem Niemieckiej Izby Przemysłu i Handlu. W artykule przedstawiony jest sposób w jaki powiązano tę nową gałąź edukacji państwowej z wymaganiami kwalifikacji i certyfikacji wg EN ISO 9712.

\section{First approach - proficiency testing in NDT}

Since 2009, the German Society for NDT (DGZfP) is offering proficiency testing for the following non-destructive testing methods:

- Visual Testing (VT),

- Penetrant Testing (PT),

- Magnetic Testing (MT),

- Radiographic Testing (RT),

- Ultrasonic Testing (UT).

Accredited and non-accredited NDT service providers whose test personnel is participating in a recertification course in one of the DGZfP training centres (Berlin, Dortmund or Munich) can additionally participate in a proficiency test.

DIN EN ISO/IEC 17025:2005 „General requirements for the competence of testing and calibration laboratories" demands guaranteed quality of test results (chapter 5.9). This applies also to the results of nondestructive testing. Participation in proficiency tests is one appropriate measure of quality assurance and projected surveillance of the "validity of performed testing". 


\section{Performance}

In connection with a recertification test of level 1 or level 2 for one of the NDT methods mentioned above the test personnel of the participating NDT service provider is testing an additional test specimen. Up to now proficiency tests for the following NDT methods and related test sample are offered by DGZfP are presented in table.

Thereafter the test reports are evaluated at the headquarter of DGZfP. The test specimen is selected out of a pool of special test specimens by the respective department of DGZfP.

The result of the proficiency test is compared with a value obtained from available test results (VT 1.) or a reference value (all other proficiency tests).

The statistical evaluation and the criteria for the evaluation of the proficiency test were developed in co-operation with representatives from DAP $\mathrm{GmbH}$ (former German accreditation body, Sector Committee "Non-Destructive Testing and Joining Technology") and by consulting experts at the Federal Institute of Materials Research and Testing (BAM, Department S.1 "Quality in Testing").

Table. Proficiency tests for NDT methods and related test sample offered by DGZfP

Tablica. Metody badań nieniszczących i powiązane z nimi próbki do badań oferowane przez DGZfP

\begin{tabular}{|c|c|c|}
\hline VT & $\begin{array}{l}\text { 1. Inner inspection of } \\
\text { a pipeline }\end{array}$ & $\begin{array}{l}\text { 2. Testing of a welded } \\
\text { plate }\end{array}$ \\
\hline PT & $\begin{array}{l}\text { 1. Testing of a } \\
\text { welded plate }\end{array}$ & - \\
\hline MT & $\begin{array}{l}\text { 1. Testing of a } \\
\text { welded plate }\end{array}$ & - \\
\hline RT & $\begin{array}{l}\text { 1. Testing of a } \\
\text { welded pipeline }\end{array}$ & - \\
\hline UT & $\begin{array}{l}\text { 1. Testing of a } \\
\text { welded plate }\end{array}$ & 2. Testing of a T-joint \\
\hline
\end{tabular}

\section{Test task}

As an example the test task is described using penetrant testing. In this case the task of the proficiency test consists of the inspection of the weld of a welded sheet (process sample of a vessel welded seam). The specimen consists of construction steel S355J2. Penetrant testing should be performed at the face side of the weld, according to EN 571-1 with a acceptance level 2X acc. to DIN EN ISO 23277.

The test procedure should be reported on a test record sheet, which corresponds to a chart-like inspection report.

\section{Homogeneity and stability check of samples \\ The homogeneity and stability check which is re- quested by ISO 13528 (chapter 4.4), means the control of the consistent, homogeneous composition of one or more determined properties is not applicable, because}

the inhomogenities of the test specimens are inserted artificially.

\section{Statistical evaluation}

The statistical evaluation of the proficiency test results is performed in line with

- ISO/IEC Guide 43-1:1997 „Proficiency testing by interlaboratory comparisons",

- ISO 13528:2009 „Statistical methods for use in proficiency testing by interlaboratory comparisons".

The evaluation is performed in two parts:

\section{The z-score}

Location and size of indications are evaluated. The respective test specimen contains three indications which have to be recorded.

The reference value was determined by a test laboratory accredited for the respective test method.

The precision of location and especially of the size of the indication mainly depends on the precise performance of the penetrant testing conforming to standards. A deviation of up to $5 \mathrm{~mm}$ with respect to the location and length indication is realistic within practice of non-destructive testing.

Therefore, a standard deviation of $2.5 \mathrm{~mm}$ was agreed. This means that the resulting z-score (see below) refers to a "questionable" test result in the case of a deviation larger than $5 \mathrm{~mm}$ while test results with a deviation up to $5 \mathrm{~mm}$ are regarded as acceptable result. A standard deviation of $1 \mathrm{~mm}$ for the size of nonlinear indications was defined.

Based on the determined reference value and standard deviation the z-score is calculated as follows:

$\mathrm{z}-$ score $=\frac{\text { reference value }- \text { results of proficiency test }}{\text { standard deviation }}$

The z-score enables the evaluation of the proficiency test. The value is defined in standard ISO 13528 (chapter 3.5) as standardized measure of laboratory bias, calculated using the assigned value and the standard deviation for proficiency assessment.

Acc. to ISO/IEC Guide 43-1 (A.3.1.1) and ISO 13528 (7.4.2, Interpretation of Z-scores) the following is essential:

\section{$|z| \leq 2$ - the proficiency test was performed successfully}

The penetrant testing was performed in line with the standards and following to the test instruction. No measures for quality assurance of the performance of penetrant testing are required.

\section{$2<|z|<3-$ the result of the proficiency test is questionable}

The principle of operation of the NDT inspector who has performed the respective proficiency test should be supervised and monitored by the NDT service provider. The reason for the deviating test result can be related, for example, to the imprecise application of the testing 
equipment, lack of knowledge of the standards, imprecise test record, wrong determination of registration level etc.

$|z| \geq 3$ - the proficiency test was not successful.

In this case the value for the location and/or size of minimum one recordable indication was recorded outside the given tolerance or minimum one recordable indication was not detected. The NDT service provider is asked to evaluate the reason and to take measures such as training in the performance of penetrant testing to standards, appropriate application of testing equipment, precise recording in line with the test instruction, detailed knowledge of the standards etc. These measures have to be monitored and recorded.

\section{Evaluation acc. to EN ISO 9712}

The evaluation of the performance of the penetrant testing is carried out according to EN ISO 9712. Besides the detection and recording of all indications which are to be registered, the recording and the correct application of the standards for penetrant testing are of importance, too.

In the second part of the proficiency test the performance of the testing, knowledge of test equipment, recording of test results is evaluated in dependence on the assessment criteria of the standard (EN ISO 9712, practical PT examination level 2) by the organizer of the proficiency test.

The proficiency test was successful if $70 \%$, means minimum 59.5 points of 85 points demanded by the standard, are achieved.

\section{Conclusion}

Proficiency tests are one measure to confirm the consistent quality in the performance of NDT. However, one always has to consider the practical application of the NDT method with its limitations. In NDT, we quite often do not actually measure - this is not possible in all cases - but quite often we can only estimate the location, length or height of an indication. Therefore a realistic tolerance must be attributed to the reference value. Under this consideration, proficiency tests organized by DGZfP show the level of quality in the performance of NDT of an NDT service provider.

\section{Second approach - vocational education}

In Germany vocational training takes place under the umbrella of the German Chamber of Industry and Commerce. It is a dual system consisting of theoretical training at State vocational schools and practical training at the premises of the apprentice training company.
Until July 2013, vocational training in materials testing was offered only in the area of metal technique or heat treatment technique. The training requirement and content of the examination are layed down in a decree which is published in the German Official Journal.

In 2010 a review of this decree was decided and DGZfP as well as representatives of plastic materials sector took the chance to include their sector into the new law. As this was agreed by the German key employer and employee organizations within a relatively short time of one and a half years a group of nominated experts out of the different industrial sectors drafted a new legislation. Starting from August 1st this year the profession of materials tester is trained in four different disciplines:

- Metal Technique,

- Heat Treatment Technique,

- Plastic Materials Technique,

- System Technique.

System Technique includes the specialization of materials testing of components and in plants and technical systems by predominantly using non-destructive testing methods.

The first part of the examination takes place after approx. eighteen months. Up to this date all disciplines are trained together, so that all materials testers have equal basic knowledge. Thereafter they separate and specialize in their discipline. Examination Part 1 requires the following methods in the practical part:

- tensile testing,

- hardness testing,

- visual testing,

- penetrant testing,

- micro-section,

- light microscopic measurement.

Figure shows which NDT methods are trained (theory only) at State vocational schools. Furthermore it shows that after examination Part 1 NDT methods are continued for discipline System Technique only. The other materials tester disciplines specialize in their technical directions: destructive testing, testing of plastic material or heat treatment.

After three and a half years practical and written examination Part 2 at the end of the education takes place in the specific discipline. For System Technique the requirements are: two examinations

\section{Practical examination}

Performance of NDT at the company, delivery of a detailed test report, presentation of the NDT test performed and interview about it in front of the examination committee

\section{Written examination}

- preparation of a test instruction for a NDT,

- performance of NDT surface defect testing,

- specific requirements of NDT in technical systems and facilities.

The two German certification bodies for NDT personnel, DPZ and Sector CERT, agreed to acknowledge 


\section{Non-Destructive Testing at Vocational Schools}
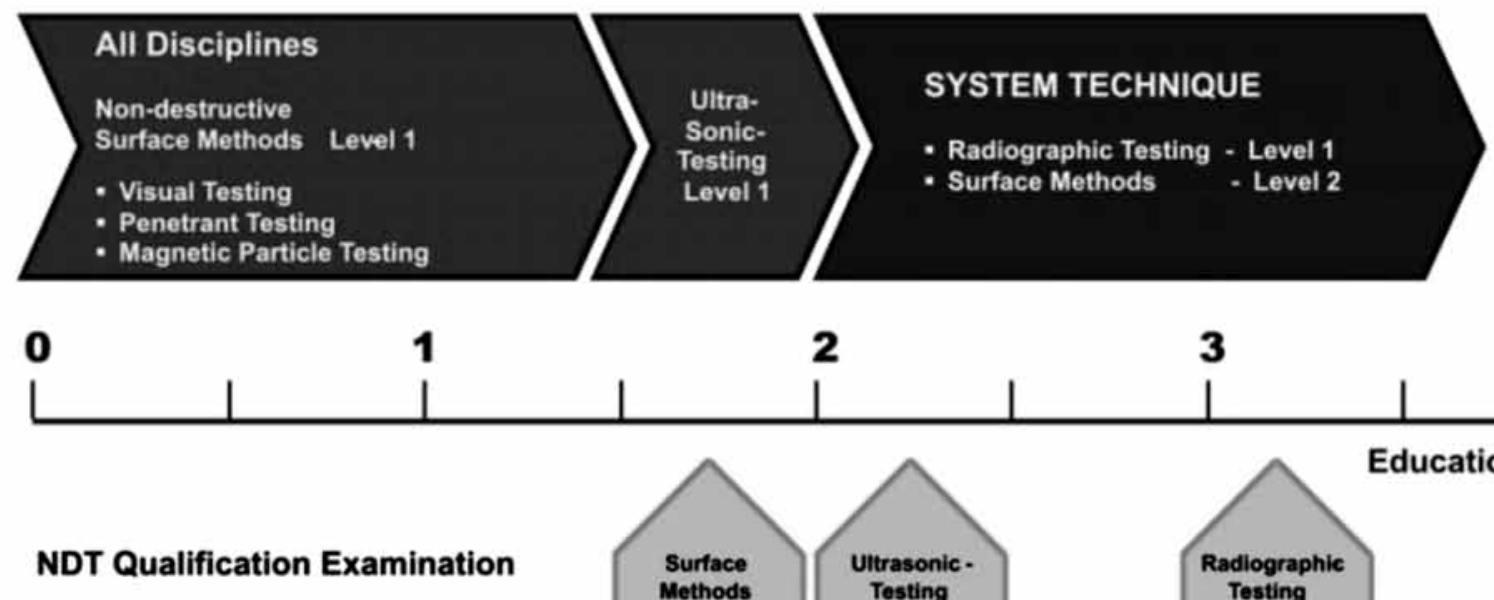

NDT Qualification Examination

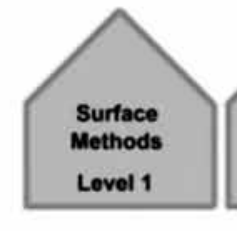

2

3
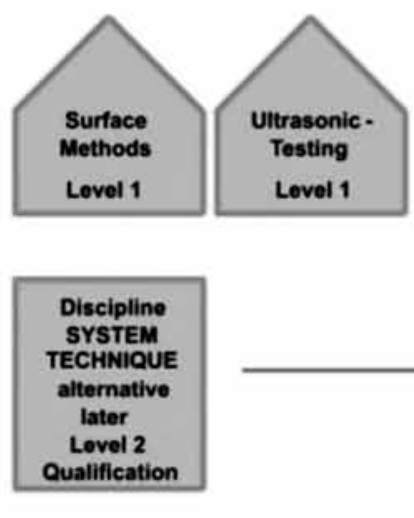

Education Year

Fig. NDT at Vocational Schools

Rys. NDT w niemieckich szkołach państwowych

the theoretical NDT training at vocational schools and the practical training at the NDT company if it is precisely recorded in a specific report portfolio. So the trainee does not have to repeat the complete subjectmatter and exercise but in the best case only one or a few refreshing training days followed by the qualification examination. The number of days depends on the NDT method and the level.

\section{Conclusion}

This new German vocational education law enables NDT companies to train their secondary growths in the field of NDT from the basics. The trainees have good knowledge of the different materials, destructive testing methods as well as non-destructive methods and application of NDT in technical systems and facilities.

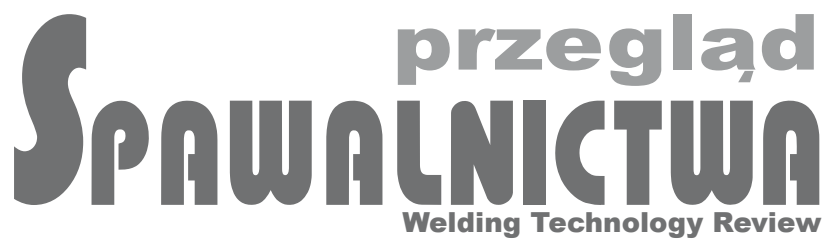

Redakcja Przegląd Spawalnictwa, ul. Świętokrzyska 14a, 00-050 Warszawa tel.: 2282725 42, fax: 2233614 79; e-mail: pspaw@ps.pl, www.pspaw.ps.pl 